\title{
Penggunaan Na-Keiyoushi dalam Lagu L'Arc en Ciel Album True
}

\author{
Agus Mauludin*, Ely Triasih Rahayu, Anggita Stovia \\ * Program Studi Sastra Jepang, Universitas Jenderal Soedirman, Indonesia \\ e-mail: agus.mauludin@mhs.unsoed.ac.id
}

\section{Abstract}

This research aims to describe the formation and the meaning of na-keiyoushi that exist in the song lyrics of L'Arc en Ciel in True Album. The theory that will be use is adjectiva $\sim$ na (na-keiyoushi), morphology, and semantic. The data research is from the fragments of song lyrics from 7 songs used as data source. Method that will be used is descriptive and kualitative methods. Data accumulated done by see-note technique. According to the analysis result there are 17 data found: 1 ) Classification of adjectiva $\sim n a$ according to shape there are 3 (three) classifications such as: a) "Adjective $\sim n a$ that followed by kopula (shuusheikei)" (2 data), b) "Adjective $\sim n a$ that explains verb (renyoukei)" (2 data), and c) "Adjective na that explains noun (rentaikei)" (13 data) ; 2) Classification of adjective $\sim n a$ according to its meaning, such as this research, a) States a physical condition, b) States human character, c) States condition of a certain place, d) States feelings, e) States nature condition, f) States time, and g) States an object's condition. Data that most widely shown up is the shape rentaikei that meaning is stating feeling. According to the research result we could conclude that in the song lyrics of adjective $\sim$ na used to state feelings.
\end{abstract}

\section{Keywords:}

Morfologi; Semantik;

Pembentukan; Makna;

Adjektiva $\sim \mathrm{Na}$

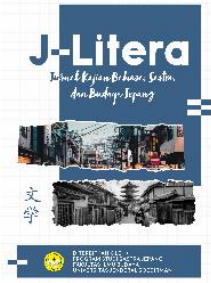

Article Info:

First received:

18 February 2021

Available online:

28 May 2021

\section{PENDAHULUAN}

Bahasa digunakan sebagai media untuk berinteraksi dengan orang lain. Dengan bahasa seseorang dapat menyampaikan maksud atau makna, baik secara lisan maupun tertulis. Bahasa digunakan sebagai alat untuk menyampaikan sesuatu yang terlintas dalam hati, seperti gagasan, pikiran, atau perasaan. Oleh karena itu, setiap bahasa memiliki makna yang terikat dengan apa yang akan disampaikan oleh penutur kepada lawan tutur.

Manusia tidak mungkin dapat hidup tanpa bahasa, karena dengan bahasa seseorang mampu menyampaikan berbagai jenis informasi. Menurut (Sutedi, 2009) bahasa digunakan sebagai alat untuk menyampaikan sesuatu ide, pikiran, hasrat dan keinginan. Dengan ini menyatakan bahwa bahasa berperan penting bagi manusia dalam kehidupan sehari hari, dan juga diperlukan untuk menjalankan segala aktivitas hidup manusia. Menurut Chaer (1994:1) ilmu tentang bahasa atau ilmu yang menjadikan bahasa sebagai objek kajianya yaitu linguistik. Linguistik umum dibagi menjadi beberapa cabang, dalam penelitian ini akan mengkaji 2 dari cabang linguistik umum yaitu morfologi dan semantik.

Morfologi atau morphology secara harfiah dapat disebut sebagai ilmu yang mempelajari tentang perubahan bentuk. Menurut (Verhaar, 1996) morfologi yaitu cabang linguistik yang mengidentifikasi satuan - satuan dasar bahasa sebagai satuan yang gramatikal. Dalam linguistik, morfologi merupakan ilmu proses pembentukan fungsi struktur kata dan kemudian membentuk kombinasi kata yang berupa morfem. Menurut para ahli menyatakan morfem adalah satuan gramatikal terkecil yang mempunyai makna (Chaer, 2003).

Semantik merupakan salah satu bagian dari linguistik umum yang mempelajari tentang makna kata, frasa dan klausa dalam suatu kalimat. Dalam linguistik peranan semantik sangat penting dalam kehidupan berkomunikasi, karena bahasa yang digunakan dalam berkomunikasi adalah untuk menyampaikan makna. Menurut (Chaer, 2009) kata semantik dapat diartikan sebagai ilmu 
tentang makna atau tentang arti, yaitu salah satu dari tiga tataran analisis bahasa berupa fonologi, gramatika dan semantik. Dengan kata lain semantik adalah bidang studi linguistik yang mempelajari tentang arti dan makna dalam bahasa.

Bahasa Jepang adalah salah satu bahasa yang sulit untuk dipelajari. Hal ini disebabkan karena terdapat karakteristik tersendiri yang terkandung dalam kosakata bahasa Jepang. Banyaknya pola kalimat dan kata yang memiliki bentuk atau makna yang hampir sama juga menjadi penyebab pembelajar bahasa Jepang mengalami kesulitan dalam memahami kalimat bahasa Jepang. (Sudjianto \& Dahidi, 2004) mengungkapkan bahwa dalam bahasa Jepang terdapat sepuluh kelas kata, yaitu : doushi verba'「動詞」, keiyoushi 'adjektiva i'「形 容詞」, keiyoudoushi 'adjektiva na' 「形容動 詞」, meishi 'nomina'「名詞」, fukushi ‘ adverbia'「副詞」, setsuzokushi 'konjungsi'

「接続詞」, rentaishi 'prenomina'「連体詞」 , kandoushi 'interjeksi'「感動詞」, jodoushi“ verba bantu'「助動詞」, dan joshi 'partikel ,「助詞」.

Kelas kata atau dapat disebut dengan hinshi bunrui 「品詞分類」 terdiri dari 10 kelas kata, salah satu kelas kata yang sering digunakan untuk mendeskripsikan orang atau benda sebagai salah satu cara untuk memberikan ciri ciri pembeda dengan yang lain yaitu keiyoushi ' adjektiva'「形容詞」. Keiyoushi merupakan kata untuk menerangkan objek atau meishi, nomina'「名詞」.

Dalam bahasa Jepang, adjektiva disebut dengan keiyoushi「形容詞」. Menurut Kitahara (dalam Sudjianto \& Dahidi, 2004), keiyoushi adalah kelas kata yang menyatakan sifat atau keadaan berbagai keadaan, berfungsi sebagai predikat dan atribut. Keadaan yang dimaksud pada kalimat tersebut dapat berupa keadaan benda dan perasaan.

Diiringi perkembangan zaman semakin pesat, munculah para ahli seniman musik di berbagai belahan dunia menciptakan berbagai lagu. Isi lagu tersebut bertujuan sebagai media untuk menyampaikan pesan berupa isi hati sang pengarang, didalam lirik tersebut memiliki arti dan makna lebih dalam seperti mengungkapkan perasaan, kode, imajinasi dan lainya. Dari ribuan pengarang musik di seluruh dunia, seiring berganti tahun jumlah pengarang semakin meningkat. Ada salah satu grup band musik yang cukup populer berasal dari Jepang bernama L'Arc en Ciel yang menarik untuk diteliti.

L'Arc en Ciel "Raruku An Shieru" dalam bahasa Prancis jika diartikan memiliki arti kata 'lengkungan di langit' atau bisa disebut dengan 'pelangi'. Grup musik L'Arc en Ciel merupakan nama grup musik asal Jepang yang beraliran $J$ Rock (Japanese Rock). Band ini beranggotakan empat orang yang terdiri dari Hyde (vokal), Ken (gitar), Tetsuya (bass), dan Yukihiro (drum). Grup musik ini didirikan oleh Tetsuya pada Februari tahun 1991.

Nama L'Arc en Ciel diambil dari sebuah judul film Perancis yang pernah ditonton oleh Tetsuya. L'Arc en Ciel sudah mengeluarkan beberapa album, salah satunya album True yang merupakan album keempat mereka. Album ini dirilis di Jepang pada tanggal 12 Desember tahun 1996. Album ini berisi 10 lagu, yaitu Fare Well, Caress of Venus, Round and Round, Flower, Good Morning Hide, the Fourth Avenue Cafe, Lies and Truth, Kaze ni Kienaide, I Wish, dan Dearest Love. Lagu yang akan menjadi sumber penelitian ini terdiri dari 7 lagu, yaitu Caress of Venus, Flower, I Wish, Kaze ni Kienaide, the Fourth Avenue Cafe, Lies and Truth, dan Round and Round.

\section{TINJAUAN PUSTAKA}

Dalam penelitian ini penulis memaparkan tiga penelitian terdahulu yang ralevan dengan permasalahan yang akan dibahas pada penelitian ini. Adapun penelitian terdahulu yang relevan dengan penelitian ini diantaranya:

Penelitian Nasution (2017) yang berjudul "Analisis Kontrastif Adjektiva Kirei dalam Bahasa Jepang dan Adjektiva Cantik dalam Bahasa Indonesia". Pada penelitian tersebut mengkaji tentang struktur dan makna adjektiva kirei dalam bahasa Jepang, dan adjektiva cantik dalam bahasa Indonesia. Adjektiva kirei dan adjektiva cantik memiliki beberapa persamaan dan perbedaan, yaitu kirei dapat berfungsi sebagai predikat, atribut dan konjungtif dalam kalimat, sedangkan cantik dapat berfungsi sebagai predikat, atribut dan adverbial dalam kalimat. Makna dari kirei dapat menunjukkan wajah, tempat, pemandangan, warna, bunyi, 
hewan, hati, benda (sebuah karya), penampilan, habis, hilang, rapi dan bersih, sedangkan makna dari cantik dapat menunjukkan wajah, benda, warna, hewan, hati, penampilan, tanaman, pemandangan, dan tempat.

Metode penelitian yang digunakan adalah deskriptif kualitatif dan pendekatan konstrantif. Deskriptif kualitatif yaitu menganalisis data dengan cara membuat penjelasan berupa gambaran secara sistematis, dan didalamnya berisikan data faktual yang akan diteliti. Pendekatan konstrantif digunakan sebagai tahap penelitian tersebut yang bertujuan untuk membandingkan dua atau lebih fenomena bahasa dan mengontraskan keduanya.

Persamaan penelitian Nasution (2017) dengan penelitian ini memiliki tujuan dan maksud yang sama yaitu mendeskripsikan makna pada adjektiva dalam bahasa Jepang yang dianalisis menggunakan teori semantik. Metode penelitian pada data tersebut juga memiliki cara penjelasan yang sama yaitu dengan memaparkan hasil analisis data berupa gambaran sistematis berdasarkan fakta dari data yang diteliti.

Perbedaan penelitian tersebut terletak pada teknik membandingkan data yang bertujuan untuk mengetahui persamaan dan perbedaan struktur dan makna pada kata kirei dan cantik, serta pada penelitian ini tidak menyertakan teori leksikal.

Penelitian kedua dilakukan oleh Korompis (2015) yang berjudul "Penggunaan adjektiva $\Gamma$ $\mathrm{I}\lrcorner$ dan $\lceil\mathrm{Na}\lrcorner$ dalam Kalimat Bahasa Jepang” . Hasil penelitian tersebut memaparkan bahwa adjektiva $\sim i$ mengalami perubahan wujud pada akhir katanya, dan berfungsi untuk menerangkan / menjelaskan suatu kondisi / keadaan suatu benda. adjektiva $\sim$ na tidak mengalami perubahan wujud, tetapi hanya dibubuhi dengan akhiran berupa frasa, kopula, atau posposisi. Walaupun begitu, fungsinya tetap sama seperti pada adjektiva $\sim i$ yaitu untuk menerangkan / menjelaskan suatu kondisi / keadaan suatu benda.

Tahap penelitian tersebut menggunakan metode penelitian deskriptif yaitu metode yang dilakukan untuk menggambarkan dan menjabarkan suatu permasahan dengan menyertai data yang sebenarnya.
Penelitian Korompis (2015) memiliki persamaan dengan penelitian ini yaitu pada tahap analisis data tersebut membahas makna adjektiva $\sim n a$, penggunaan adjektiva $\sim n a$ dalam suatu kalimat, dan perubahan bentuk adjektiva $\sim n a$.

Sementara itu, perbedaan dengan penelitian Korompis (2015) yaitu dalam penelitian ini hanya membahas data yang berisikan adjektiva $\sim n a$, sedangkan pada penelitian Korompis (2015) membahas tentang adjektiva $\sim i$ dan adjektiva $\sim n a$.

Penelitian ketiga dilakukan oleh Duduong (2017) yang berjudul "Analisis Makna dan Penggunaan Iroiro-na dan Samazama-na dalam Kalimat Bahasa Jepang". Juniati Duduong (2017) menganalisis tentang persamaan dan perbedaan makna iroiro-na dan samazama-na dalam kalimat bahasa Jepang berdasarkan kajian semantik. Kata iroiro-na dan samazama-na jika diartikan memiliki arti 'macam - macam', namun maknanya dapat berubah sesuai penggunaan pada kalimat bahasa Jepang. Perbedaan dari kedua kata tersebut yaitu adjektiva iroiro-na digunakan untuk menyatakan pendapat atau menjelaskan jenis - jenis dari nomina, sedangkan adjektiva samazama-na digunakan untuk menyatakan penampilan, keberadaan, kondisi, dan alam.

Metode penelitian Duduong (2017) menggunakan metode kepustakaan, yaitu dengan menelusuri sumber-sumber pustaka berupa buku teks, e-book, jurnal, dan skripsi yang memiliki hubungan dan dapat menunjang pemecahan masalah penelitian ini.

Persamaan pada penelitian yang dilakukan oleh Duduong (2017) yaitu kajian yang dianalisis menggunakan teori semantik. Data yang dianalisis berfokus pada pembahasan makna adjektiva $\sim n a$ dan penggunaan adjektiva $\sim n a$.

Perbedaan penelitian Duduong (2017) dengan peneilitian ini yaitu pada Duduong (2017) hanya membahas makna dan penggunaan adjektiva $\sim n a$, sedangkan penelitian ini membahas makna, penggunaan kata, dan perubahan bentuk adjektiva $\sim n a$. Selain itu, pada penelitian tersebut menjelaskan persamaan dan perbedaan dari dua jenis adjektiva yang berbeda. 


\section{METODE PENELITIAN}

Jenis penelitian ini menggunakan metode deskriptif kualitatif. Penelitian deskriptif kualitatif adalah penelitian yang berdasarkan pada fakta yang ada atau fenomena yang secara empiris hidup pada penutur - penuturnya sehingga apa yang dihasilkan atau dicatat berupa pemerian bahasa yang biasa dikatakan sifatnya seperti potret paparan seperti apa adanya (Sudaryanto, 1992). Tujuan Penelitian deskriptif kualitatif pada dasarnya yaitu untuk mengungkapkan kejadian atau fakta, keadaan, fenomena, variabel dan keadaan yang terjadi saat penelitian berlangsung dengan menyuguhkan apa yang sebenarnya terjadi.

\section{ANALISIS DAN PEMBAHASAN}

\section{Adjektiva $\sim n a$ diikuti kopula}

Adjektiva $\sim n a$ yang diikuti kopula, baik diikuti kopula bentuk futsuutai yaitu da / datta atau bentuk teineigo yaitu bentuk desu / deshita. Kopula $\sim$ da berkaitan dengan keterangan waktu merupakan bentuk miraikei atau kondisi yang belum terjadi.

$\begin{array}{lllll}\text { 連れて } & \text { 行けたら } & \text { 素敵 } & \text { だ } & \text { ね } \\ \text { Tsurete } & \text { iketara } & \text { suteki } & \text { da } & \text { ne } \\ \text { Verb. } & \text { Verb. } & \text { Adj. } & \text { Part. } & \text { Part. } \\ \text { Mengantar } & \text { jika pergi } & \text { indah } & & \end{array}$

'Jika kuantar pergi ke tempat itu sepertinya akan indah'.

(Data.01/Caress of Venus)

Kalimat adjektiva $\sim$ na (na-keiyoushi) yang diikuti kopula ditunjukan pada kata suteki. Akhiran na pada adjektiva suteki dihilangkan karena kalimat tersebut diikuti kopula bentuk $「$ 普通体」 futsuutai yaitu $\sim d a$. Kopula $\sim d a$ berkaitan dengan keterangan waktu merupakan bentuk miraikei atau kondisi yang belum terjadi.

Kata suteki pada kalimat di atas bermakna ' indah' . Jika di analisis, konteks kalimat「連れ て行けたら素敵だね」, memiliki verba「連れて $」$ yang bermakna 'mengantar'. Kata「連れ $て 」$ diikuti oleh kata「行けたら」 yang bermakna 'kalau pergi' . Kata「行けたら」 merupakan verba bentuk 「行<」yang diakhiri bentuk「たら」. Pada kalimat di atas, adjektiva $\sim n a$ sama halnya dengan data nomor 1 . Kata suteki karena diikuti kopula $\sim$ da maka akhiran na dihilangkan menjadi「連れて行けたら素敵 だね」 yang diartikan 'jika kuantar pergi ke tempat itu sepertinya akan indah’.

Pembentukan adjektiva sutekida pada kalimat di atas merupakan jenis perubahan shuushikei. Seperti yang telah dijelaskan di atas, shuushikei merupakan bentuk kamus atau kata yang digunakan pada akhir kalimat.

\section{Adjektiva $\sim$ na untuk menerangkan verba}

Adjektiva $\sim$ na digunakan untuk memberikan keterangan perbuatan atau tindakan yang dilakukan oleh subjek dalam kalimat. Adjektiva $\sim$ na bila diikuti predikat atau kata yang menunjukan pekerjaan, maka akhiran $\sim n a$ akan berubah menjadi partikel $\sim$ ni.

$\begin{array}{llll}\text { 季節 } & \text { は } & \text { 穏やか } & \text { に } \\ \text { Kisetsu } & \text { wa } & \text { odayaka } & n i \\ \text { Noun. } & \text { Part. } & \text { Adj. } & \text { Part. } \\ \text { Musim } & & \text { tenang } & \end{array}$

終わりを告げた ね owari wo tsugeta ne Verb. Part.

Telah berakhir

'Musim telah berakhir dengan tenang'.

(Data.03/the Fourth Avenue Cafe)

Kalimat adjektiva $\sim$ na (na-keiyoushi) ditunjukan pada kata odayaka. Akhiran $\sim$ na pada adjektiva odayaka berubah menjadi partikel $\sim n i$, karena kalimat tersebut diikuti oleh kata yang menunjukan perbuatan atau pekerjaan.

Kata odayaka pada kalimat di atas bermakna 'tenang' . Jika di analisis, konteks kalimat $「$ 季節は穏やかに終わりを告げたね」，memiliki kata「季節」 yang bermakna 'musim'. Diikuti adjektiva「穏やか」bermakna 'tenang '. Akhiran na pada kata「穏やか」berubah menjadi partikel $\sim n i$, karena kalimat tersebut diikuti oleh kata yang menunjukan perbuatan atau pekerjaan. Kata「終わりを告げた」 memiliki makna 'telah berakhir'. Urutan kata tersebut menerangkan bahwa「季節」atau 'musim telah berakhir'. Ungkapan 'telah berakhir' karena diikuti oleh kata「穏やか」 maka bermakna 'telah berakhir dengan tenang ’. Sehingga kalimat「季節は穏やかに終わりを 
告げたね」 dapat diartikan ' musim telah berakhir dengan tenang' .

Pembentukan kata pada adjektiva odayakani termasuk dalam jenis perubahan renyoukei. Seperti yang telah dijelaskan di atas, renyoukei merupakan adjektiva diikuti oleh kata yang menunjukan perbuatan atau pekerjaan.

\section{Adjektiva $\sim n a$ untuk menerangkan nomina}

Adjektiva $\sim n a$ bila diikuti nomina maka akhiran $\sim n a$ pada adjektiva tetap digunakan.

$\begin{array}{lll}\text { 真っ白な } & \text { その } & \text { 肌 } \\ \text { Masshirona } & \text { sono } & \text { hada } \\ \text { Adj. } & \text { Noun. } & \text { Noun. } \\ \text { Putih } & \text { itu } & \text { kulit }\end{array}$

'Kulit yang putih itu'.

(Data.05/Caress of Venus)

Kalimat adjektiva $\sim$ na (na-keiyoushi) ditunjukan pada kata masshiro. Akhiran na pada adjektiva masshiro tidak berubah, karena kalimat tersebut diikuti oleh objek atau nomina yang akan diterangkan.

Kata masshiro pada kalimat di atas bermakna 'putih' . Jika di analisis, konteks kalimat「真 つ白なその肌」, memiliki kata「真っ白」yang bermakna 'putih'. Adjektiva $\sim$ na diikuti oleh akhiran na pada kata「真っ白」, karena menerangkan objek atau nomina yaitu「その肌 $」$ yang bermakna ' kulit itu'. Sehingga kalimat「真っ白なその肌」 dapat diartikan kulit yang putih itu’.

Pembentukan kata pada adjektiva masshirona termasuk dalam jenis perubahan rentaikei. Seperti yang telah dijelaskan di atas, rentaikei merupakan adjektiva yang diikuti oleh objek atau nomina.

\section{KESIMPULAN}

Pada bab ini, akan disampaikan hasil berdasarkan penelitian penggunaan adjektiva $\sim$ na pada lirik lagu L'Arc en Ciel dalam album True yang menggunakan pendekatan morfologi dan semantik. Pendekatan morfologi digunakan untuk menganalisis struktur perubahan bentuk kata pada penggunaan adjektiva $\sim$ na (na- keiyoushi). Sedangkan pendekatan semantik digunakan untuk menganalisis makna tiap kata dan mendeskripsikan berupa penjelasan sistematika yang terdapat pada penggalan lirik lagu L'Arc en Ciel dalam album True.

\section{Pembentukan Kata}

Berdasarkan 17 data yang telah dianalisis, bentuk shuushikei ditemukan sebanyak 2 data, bentuk renyoukei ditemukan sebanyak 2 data, dan bentuk rentaikei ditemukan sebanyak 13 data. Selain itu, ditemukan beberapa karakteristik lain dari pembentukan shuushikei, renyoukei, dan rentaikei pada adjektiva $\sim n a$ (nakeiyoushi), yaitu :

\section{a. Shuushikei}

1) Bentuk kata yang digunakan pada akhir kalimat

2) Pada bentuk waktu miraikei, kata sfiat $\sim$ na berubah menjadi kopula bentuk $\sim d a$

3) Pada bentuk waktu kakokei, kata sfiat $\sim$ na berubah menjadi kopula bentuk $\sim$ datta.

b. Renyoukei

1) Perubahan pada adjektiva $\sim$ na selalu diikuti verba

2) Adjektiva $\sim n a$ digunakan untuk memberikan keterangan perbuatan atau tindakan

3) Akhiran na dapat berubah menjadi bentuk $\sim n i$ atau bentuk $\sim d e$.

\section{c. Rentaikei}

1) Adjektiva $\sim$ na tidak mengalami perubahan bentuk

2) Digunakan untuk menerangkan objek atau nomina

3) Bentuk rentaikei juga dapat disebut bentuk kamus.

\section{Makna}

Berdasarkan 17 data yang telah dianalisis, ditemukan 7 makna adjektiva $\sim$ na (na-keiyoushi), yaitu :

a. Menyatakan kondisi fisik

1) 横顔でも素敵だったから (data. 02)

2) 真っ白なその肌 (data.05)

3) 真っ白な天使が舞い降りて (data.11) 
b. Menyatakan sifat manusia

1) 今も無口なままの lies (data.16)

2) 素直なまま口付けたら (data.06)

c. Menyatakan kondisi suatu tempat

1) 連れて行けたら素敵だね (data.01)

2) 君を綺麗なあの場所へ (data.07)

d. Menyatakan perasaan

1) 幸せでありますように (data.04)

2) 君は誰よりも大切な人だから (data.12)

3) 大切な愛を抱いて (data.15)

4) 誰より大切なのに (data.17)

e. Menyatakan kondisi alam

1) 鮮やかな風に誘われても (data.08)

2) 虹色に輝く素敵なときだから (data.13)

3）無機質に造られたみどりの上鮮やかな 光で (data.14)

f. Menyatakan waktu

1) 季節は穏やかに終わりを告げたね (data.03)

g. Menyatakan kondisi benda

1) 綺麗な花を敷き詰めて上げる (data.09)

2) あの素敵なオルガンに乗せて (data.10)

Berdasarkah hasil penelitian tersebut dapat disimpulkan bahwa dalam lirik lagu adjektiva $\sim n a$ digunakan untuk menyatakan perasaan.

\section{DAFTAR PUSTAKA}

Chaer, A. (2003). Linguistik Umum. Jakarta: Rineka Cipta.

Chaer, A. (2009). Pengantar Semantik Bahasa Indonesia. Jakarta: Rineka Cipta.

Duduong, J. (2017). Analisis Makna dan Penggunaan "Iroiro-na dan Samazama-na” dalam Kalimat Bahasa Jepang (skripsi). Manado: Universitas Sam Ratulangi (tidak diterbitkan).

Korompis, T. V. (Penggunaan adjektiva $\lceil\mathrm{I}\rfloor$ dan $\lceil\mathrm{Na}\rfloor$ dalam Kalimat Bahasa
Jepang). 2015. Manado: Universitas Sam Ratulangi (tidak diterbitkan).

Nasution, N. A. (2017). Analisis Kontrastif Adjektiva Kirei dalam Bahasa Jepang dan Adjektiva Cantik dalam Bahasa Indonesia (skripsi). Semarang: Universitas Diponegoro (tidak diterbitkan).

Sudaryanto. (1992). Metode Linguistik. Yogyakarta: Gajah Mada University Press.

Sudjianto, \& Dahidi, A. (2004). Pengantar Linguistik Bahasa Jepang. Jakarta: Kesaint Blanc.

Sutedi, D. (2009). Penelitian Pendidikan Bahasa Jepang. Bandung: Humaniora.

Verhaar, J. (1996). Pengantar Linguistik. Yogyakarta: Gadjah Mada University Press. 